\title{
Exploration on Educational Mechanism of Innovation and Entrepreneurship in Colleges and Universities
}

\author{
Xiaoxia $\mathrm{Wu}^{1}$ and Yanmin $\mathrm{Yu}^{2}$ \\ ${ }^{1}$ Jilin Engineering Normal University, Changchun, Jilin, 130052 \\ ${ }^{2}$ Jilin Engineering Normal University, Changchun, Jilin, 130052 \\ a516877066@qq.com
}

Keywords: Vocational colleges; Innovation and entrepreneurship education; College students; School-enterprise cooperation; Ability cultivation

\begin{abstract}
It is the advantage of vocational colleges and universities to participate in the innovation and entrepreneurship activities, but there are also some problems such as atmosphere construction, curriculum design, practical ability and teaching level. In order to solve the problems and promote the transformation and upgrading of innovative entrepreneurship, higher vocational colleges must achieve a change from the eight aspects: educational philosophy, education content, curriculum, education object, teaching staff, teaching methods, teaching resources, assessment and evaluation.
\end{abstract}

\section{Introduction}

At present, the innovation and entrepreneurship education plays a very important part in the field of higher education teaching. As the backbone of promoting the construction of modern vocational education system, higher vocational colleges should take advantage of the openness, practicality and integration of production and teaching of higher vocational education, actively integrate and serve the social economy, improve the quality of innovation and entrepreneurship education in vocational colleges, and cultivate technical talents with innovative consciousness, creative spirit and entrepreneurial ability for social and economic transformation.

\section{Two "Focus on" to Embody the Superiority of Innovation and Entrepreneurship Education in Higher Vocational Colleges}

Focus on the School-enterprise Cooperation and Strengthen the Practical Teaching. Cooperation between schools and enterprises is one of the important ways of the reform and development of higher vocational education in our country. It is the fundamental way to cultivate technical and technical talents. At present, vocational colleges focus on the close integration between personnel training and market requirements and actively build a school-enterprise cooperation platform. According to the cooperation between schools and enterprises, teachers can increase their business experiences and get a solid theoretical knowledge on the basis of continuous improvement of practical ability. At the same time, students can participate in internship training, know what does the market demand and learn the latest technology to lay the foundation for the development of innovative and entrepreneurial activities.

Focus on the Capacity Training and Have Entrepreneurial Conditions. The core of innovation and entrepreneurship education is to cultivate the innovative spirit and entrepreneurial ability of college students, guide colleges and universities to constantly update the concept of education, reform the mode of personnel training, reform the educational content and teaching methods and combine personnel training, scientific research and social service closely so as to realize a change from "focus on knowledge" to"focus more on the ability and quality" and improve the quality of personnel training[1]. The personnel training in higher vocational colleges should take the adaption of the needs of community as its goal and take the cultivation of the application technical ability as its main line, so that the innovation and entrepreneurship education has inherent favorable conditions to carry out. Mycos data show that the self-employment ratio of higher 
vocational graduates(3.9\%) in 2015 is higher than university graduates(2.1\%)[2]. This shows that vocational college students not only have a unique mode of thinking, but also have the pioneering spirit of entrepreneurship. They have more advantages in innovation and entrepreneurship activities and can be more positive.

\section{"Four deficiencies" Reflect the Lack of Innovation and Entrepreneurship Education in Vocational Colleges.}

Deficiency in the Creation of the Atmosphere. Higher vocational colleges focus on the cultivation of advanced applied talents, and the way of order talent training for the zero distance of supply and demand of schools and enterprises makes students have path dependence and lack the innovative spirit and entrepreneurial consciousness. The school's overall innovation and entrepreneurship atmosphere is not strong, scientific and technological innovation activities in campus culture and social practice activities that outside the first classroom are few and the scope of participation and the enthusiasm of students is not high.

Deficiency in the Curriculum Design. The main purpose of curriculum design in higher vocational colleges is the application, which is obviously different from the ordinary undergraduate colleges. It requires teachers to not only have the "cross - border" ability of teaching design but also have the teaching implementation ability which needs to be based on a long work process. However, the teachers in the innovation and entrepreneurship education of vocational colleges are mostly young teachers, who lack the experience of innovation and entrepreneurship, and they often repeat the teaching content of undergraduate colleges, fail to reflect the advantages and characteristics of their own and don't have a clear teaching target. They usually use the expository method and case teaching method, which are not totally based on the course content and the characteristics of the student. They lack practical curriculum and reasonable integration course and fail to combine innovative entrepreneurial courses and professional education courses closely and for students, the curriculum system is not attractive.

Deficiency in Practical Ability. The students in vocational colleges lack practical ability and social experience. At present, the innovation and entrepreneurship education in vocational colleges doesn't have the ability to transform theoretical knowledge into practice, and fail to promote an organic integration among practice, professional education and the second classroom. The vocational college students participate in the practice of school-enterprise cooperation and according to this kind of experience, they develop their manipulative ability and build a foundation for employment, but the inspiration of innovation consciousness, the ability training and the practice guidance which students can get in this process are very little. We should know that vocational students lack the real practical experience and practical management ability. The entrepreneurial competitions and the student associations are the second or third class of quality education, the number of the students who participate in this kind of activity is limited. Although the faculty advisers have certain training experience or business experience, most of them do not have entrepreneurial experience, so for students, their guidance is limited, too.

Deficiency in Teaching Level. Most professional institutions do not have specialized innovation and entrepreneurship guidance departments, teachers are generally from the school sector management staff or part of the faculty of professional teachers and most teachers lack the theoretical knowledge and practical guidance ability of innovation and entrepreneurship. The entrepreneurial projects chosen by students often have low technical content, can be easily replicated and the integration with their professional degree is not close. What's more, a large number of entrepreneurial activities halfway die, because they can not get enough support from their teachers and schools. Most of the innovation and entrepreneurship activities in the school are conducted in the form of competitions and lectures, and the lack of teaching resources has resulted in less practical activities. 


\section{"Eight Changes" to Upgrade Innovative Entrepreneurship Education in Higher Vocational Colleges}

Educational Philosophy from the "Step by Step" to "Actively Advocating". At present, the key to determine the basic trend of innovation and entrepreneurship education in colleges and universities in China is to update the concept of education and to use the new concept as the theoretical core to construct the innovation and entrepreneurship education paradigm corresponding to the construction of innovative countries[3]. The education subject of higher vocational colleges must deepen the educational idea, take the innovation and entrepreneurship education as the comprehensive quality education of college students, pay attention to the cultivation of the employment skills and development ability and integrate the quality of innovation and the awareness of entrepreneurial consciousness into the whole process of personnel training. According to the current situation of students' innovation and entrepreneurship in higher vocational colleges, we should actively carry out propaganda advocacy and demonstration guidance to create a campus atmosphere of innovation and entrepreneurship. We use the method of policy preaching, visiting and communication to make students reach a consensus and then stimulate the potential of their innovation and entrepreneurship.

Education Content from the "Basic Theory" to "Combined with Practice". The basic theory teaching of innovative entrepreneurship education can enable students to have a solid foundation, broad view and reasonable knowledge structure. From simple "entrepreneurial education" to compound "innovation education" and "creative education", the connotation of the innovation and entrepreneurship education has been further deepened in the upgrade process[4]. The innovation and entrepreneurship education in higher vocational colleges must implement the "innovative and entrepreneurial curriculum reform" on the basis of the basic theory teaching. It should rely on the professional and industrial characteristics in order to directly combine schools' training objectives with business needs, to highlight the practical ability of students, to avoid a single type of course, the disconnection from practice and other issues to promote the content and the form of the innovation and entrepreneurship education simultaneously upgrade.

Course Settings from "Independent Decentralized" to "Fusion". At present, the innovation and entrepreneurship education course of higher vocational colleges is still in the exploratory stage. It shows an independent and decentralized state and lacks standardized and scientific system design. In view of this situation, on the one hand, we should explore a new teaching mode and a new curriculum system which are suitable for the innovation and entrepreneurship education in higher vocational colleges to activate the vitality of professional education, and to integrate the professional education into the innovation and entrepreneurship education; On the other hand, we should integrate the careers guidance, career planning, the relevant public elective and the second or third classroom resources to form multiple forces. The theoretical learning, practice teaching and other links of innovation and entrepreneurship education should be linked to all kinds of courses so as to promote the cultivation of compound talents of innovation and entrepreneurship.

The Object of Education from "Universal" to "Personality". Innovation and entrepreneurship education should go to the "big stage". It should pay attention to the level of education and diversification and make sure it will benefit all the students. It should be combined with the professional education and focus on cultivating students' innovation awareness and entrepreneurial spirit to ensure the effectiveness of education. We should take the adaptability as the core, take the diversification and individuation as the characteristics and try our best to be close to the reality of students and to meet their needs. We will provide targeted guidance or training for students who participate in entrepreneurial activities and conduct entrepreneurial behavior. In the training process, we should focus on setting good examples to guide more students to actively participate in learning and activities.

Teachers from the "Relatively Single" to "Special Combination". Excellent teaching staff is the basis for ensuring the quality of teaching and learning. At present, there are many problems such as administrative part-time job, lack of quantity, lack of overall level, unreasonable team structure, lack of actual combat experience and so on, which can not meet the needs of students' innovative 
entrepreneurship education. To promote the deepening of innovation and entrepreneurship education, we must cultivate an innovative entrepreneurial education faculty with both theoretical and practical experience, reasonable structure and part-time combination[5]. On the basis of cultivating the "double-qualified" teachers' resources in the school, we will further absorb the successful entrepreneurs, the managers and the authoritative experts to enrich the innovative entrepreneurship team to realize the effective combination of school resources and social resources so that students can learn theoretical knowledge and simultaneously get effective practical guidance.

Teaching Methods from the "Scene Simulation" to "Practice Exercise". At present, the practice teaching in innovation and entrepreneurship courses in higher vocational colleges is mostly the situation simulation and the practical teaching activities are few. The education of "talking on paper" makes it impossible for students to experience the reality of "real swords and guns". If we want to improve the effectiveness of education, we must grasp the practical characteristics of innovative entrepreneurship education and carry out "practice-oriented" classroom teaching. The General Office of the State Council pointed out that it encourages scientific research institutes and universities to build a maker space around the field of dominant specialities in the "instruction of accelerating the development of maker space and the transformation and upgrading of the real economy". Higher vocational colleges can introduce or create a "maker space" which is an innovative business platform. The instructor can provide more extensive educational content, such as skill teaching, project roadshow and so on to focus on solving the practical problems in the process of work, and students' internship and entrepreneurial activities are both based on the project The project is just like a carrier and an actuator to make the innovative entrepreneurship education more and more successful.

Teaching Resources from the "Closed Independence" to "Open Sharing". Innovation and entrepreneurship education is an open education, which can not be separated from the rich teaching resources allocation. The educational resources of higher vocational colleges in China are long-term closed, and there is no exchange between schools and also the colleges lack external exchanges and cooperation. Through the integration of production and education, school-enterprise docking, inter-school communication and other ways, a series of teaching and practice platform are constructed to promote high-quality innovation and entrepreneurship education resources transformation, so that the essence of innovative entrepreneurship education can get a greater degree of release and form a open sharing, win - win innovation and entrepreneurship education.

Assessment from the "Quantitative Results" to "Ability-Oriented". Innovation and entrepreneurship education needs to change the traditional examination and evaluation methods, to create a capacity-oriented assessment and evaluation mechanism and to establish a cumulative conversion system between the innovative entrepreneurial activities and the curriculum credits. Innovation and entrepreneurship education is a series of processes from knowledge learning and simulation experience to actual combat. The particularity of the nature of education determines the unconventional nature of the assessment method. Therefore, we should establish an assessment mechanism which combines the process of assessment with the identification of the results. We should pay attention to the process of problem analysis and focus on how to solve the problem. We should respect and support the results of the innovation and entrepreneurship, and constantly stimulate students' enthusiasm on it.

\section{References}

[1] X.Chen: Let the innovative entrepreneurship education throughout the whole process of university personnel training [J], China Higher Education, 2010 (12): 4-6. (In Chinese)

[2] McIntosh Research Institute: 2016 Chinese college students employment report [R], Beijing: Social Science Literature Publishing House, 2016. (In Chinese)

[3] Z.R.Wang: The overall conception of the concept of innovation and entrepreneurship education in colleges and universities [J], China Higher Education Research, 2015 (7): 75-78. (In Chinese) 
[4] X.Chen: Enhancing the Quality of "Double Creation" Education through the Combination of Industry and Education [N], Guangming Daily, 2016-05-10 (13).(In Chinese)

[5] D.Q.Jiang: College Innovation and Entrepreneurship Education Teacher Team Construction [J], China Higher Education, 2011 (10): 34-36. (In Chinese)

[6] L.W.Zhang: Theoretical Thinking and Practical Exploration of Innovation - driven urban and rural integration development [J], China Soft Science 2015 (04).(In Chinese)

[7] J.Wang: Resource Bottlenecks Are the Biggest Obstacle to Economic Development [J], China investment 2013 (10).(In Chinese)

[8] X.Y.Shi: Three Key Features of Innovation-Driven Economies and Their Policy Implications [J], China Soft Science 2015 (02).(In Chinese)

[9] B.Ye and L.Y.Chen: Research on Symbiosis Deep Simulation of Regional Innovation Network [J], China Soft Science 2015 (04).(In Chinese)

[10] Y.Hu: Enhance the Innovation - driven Development of New Impetus[J], China Soft Science 2013 (11).(In Chinese) 